Vitae Scholasticae ukazujący się w językach angielskim, hiszpańskim, francuskim lub niemieckim przy Nothern Illinois University, a wydawcą jest Lucy Towsend (Caddo Gap Press, 3145 Geary Boulevard, Snite 275, San Francisco, California 94118 USA). Zamieszcza się $w$ nim prace poświęcone teorii biografii edukacyjnej, wspomnieniom, przeżyciom, biografie pedagogiczne. Prezentuje także inne pisma naukowe i wykazy nowych ksiazżek.

Jan Hellwig

\title{
Jędrzej Sobczak, „Nowe wychowanie” w polskiej pedagogice okresu Drugiej Rzeczypospolitej (1918-1939), Wydawnictwo Uczelniane WSP w Bydgoszczy, Bydgoszcz 1998, ss. 446
}

Książka ta, na pojawienie się której na rynku wydawniczym od dawna czekano, jest drugim, zmienionym wydaniem pracy Jędrzeja Sobczaka, która jako dwuczęściowa monografia ukazała się pod tytułem Recepcja idei „nowego wychowania" w polskiej pedagogice okresu miedzy wojnami (Bydgoszcz 1978-79). Autor ukazuje w niej przemiany, jakim w okresie Drugiej Rzeczypospolitej ulegała teoria i praktyka wychowawcza pod wpływem rozwijającego się od początku XX wieku w krajach Europy i Stanach Zjednoczonych ,ruchu nowego wychowania”. Dynamikę tych przemian przedstawiono poprzez przytoczenie teoretycznych rozważań i podanie praktycznych przykładów rozwiązań wychowawczych podejmowanych w tym czasie w Polsce.

Na podstawę do prezentowanych w pracy ustaleń złożyła się uważna lektura niezmierzonej ilości książek, broszur oraz artykułów z zakresu ówczesnego piśmiennictwa pedagogicznego. Zamierzeniem autora jest również przybliżenie wspólczesnemu czytelnikowi, na łamach swej książki, wielu interesujących pozycji pedagogicznych, wydanych wówczas, a stosunkowo słabo dzisiaj znanych.

Krzysztof Jakubiak

\section{Bibliografia historii wychowania (druki zwarte wydane w Polsce w L. 1997-1998)}

Andrzejak A., Nawrocka M., Wąsikowska-Trawińska A, Śladami Dokty. Wanda Bleńska - nadanie imienia Piqtkowskiej Szkole Uspolecznionej w Poznaniu, Poznań 1997, ss. 77;

Ars Edukandi, T. 1, Gdańsk 1998, ss. 248;

Bachta E., Mlodzieżowe konspiracyjne organizacje niepodlegościowe $w$ województwie rzeszowskim w latach 1944 - 1956, Przemyśl 1997, ss. 231;

Banach A.K, Mlodzież chlopska na Uniwersytecie Jagielloniskim w latach 1860/61 -1917/18, Kraków 1997, ss. 359;
Bartnicka K., Wychowanie patriotyczne w szkolach Komisji Edukacji Narodowej, Warszawa 1998, ss. 247;

Baszkiewicz J, Mlodość uniwersytetów, Warszawa 1997, ss. 197;

Bereźnicki F., Hasla "nowej szkoly" w dydaktyce Drugiej Rzeczypospolitej, Toruń 1998; ss. 213 ;

Bieńkowski T., Jan Amos Komeński o nauczaniu i wychowaniu, Pułtusk 1998, ss. 95; 
Blendzi K., Piskorska M., Opowiemy wam o szkole: zarys historii szkolnictwa w Zytowiec$k u$ w latach 1897-1997, Żytowiecko 1997, ss. 73 ;

Blaszczyk I., Ossowska A, Rączewska V., Historia wychowania rodzinnego i ksztalcenia $w$ starożytnosci: przewodnik bibliograficzny, Bydgoszcz 1997, ss. 251;

Bogaj A., Kwiatkowski S. M., Szymański M. J., System edukacji w Polsce: osiggnięcia - przemiany - dylematy, Warszawa 1997;

Bogdan Suchodolski. Pedagog - humanista - uczony, pod red. Stopińskiej-Pająk A., Katowice 1998;

Bogucki A., Towarzystwo Gimnastyczne Sokól na Pomorzu 1891-1939, Bydgoszcz 1997, ss. 432 ;

Borkowska M., Klasztory dominikańskie w Górze Kalwarii, Góra Kalwaria 1997, ss. 139;

Bybluk M., Przemiany edukacji w Rosji u schylku $X X$ wieku. Studia $i$ szkice historyczno-pedagogiczne, Toruń 1998, ss. 216;

Chałubińska A, Kartki z autobiografii, Puławy 1997, ss. 78;

Chojnacki J., Bronislaw Chojnacki 1895 -1955: pedagog - spolecznik - polityk, Sierpc 1998;

Czech A, Profesorowie i wychowankowie Uniwersytetu Jagiellońskiego $w$ dziejach katowickiej Akademii Ekonomicznej, Katowice 1997, ss. 49;

Daszkowski E. A., Szkola Wilków Morskich, Szczecin 1998, ss. 224;

Dawid J. W., O duszy nauczycielskiej, Lublin 1997, ss. 84;

Dopke J., Katechizacja w Polsce 1945-1990, Pelplin 1998, ss. 248;

Duda J., Slownik biograficzny nauczycieli Ślqska Opolskiego, cz. 3, Opole 1997, ss. 116;
Dworzaczkowa J., Bracia Czescy w Wielkopolsce w XИ i XVII wieku, Warszawa 1997, ss.214;

Dyba M., Drogi Ślqzaków do wiedzy (XII w. - 1968 r.), Katowice 1997, ss. 63;

Edukacja kulturalna w spoleczeristwie obywatelskim, pod redakcją Żebrowskiego J., Gdańsk 1997, ss. 338;

Edukacja mlodego pokolenia Polaków i Ukraińn ców w kontekście integracji europejskiej. $\mathrm{Na}$ dzieje $i$ zagrożenia, pod redakcją Kuchy $\mathbf{R}$. i Kłosa E., Lublin 1998, ss. 483;

Filozofia wychowania Sergiusza Hessena, pod redakcj̨ Rotkiewicz H., Warszawa 1997, ss. 223 ;

Foeller W. J, Gimnazjum Collegium w Warszawie: monografia, Warszawa 1997, ss. 147;

Galicja i jej dziedzictwo, pod redakcją Majorka Cz. i Potocznego J., T. 9: Biografie pedagogiczne, Rzeszów 1997, ss. 192;

Gogolewski E., Szkolnictwo polskie we Francji (1833-1990), przekład $z$ francuskiego: Kaufman S. i Lukaszewicz J., Wroclaw 1998, ss. 250;

Historia wychowania w $X X$ wieku. Dorobek i perspektywy, pod redakcją Gumuły T., Krasuskiego J., Majewskiego S., Kielce 1998, n. 610;

Historia wychowania. Wybór źródel, wybór i opracowanie: Możdżeń S., cz. 2: Średniowiecze, Kielce 1997, ss. 111;

Jabrzemski J., Harcerze z Szarych Szeregów, Warszawa 1997, ss. 334 ;

Jadwiga $i$ Waclaw Zembrzuscy, nauczyciele $i$ dzialacze oswiatowi, przygotowanie $\mathrm{i}$ wstęp: Hellwig J., Poznań 1998, ss. 78;

Jałmużna T., Lódzkie czasopisma szkolne w latach międzywojennych, Lódź 1998, ss. 124;

Jaworski A., Szkolnictwo górnicze a przemysl weglowy Polski 1945-1989, Opole 1997/1998, ss. 264 ; 
Jezuici w Toruniu 1596-1996: materialy konferencji zorganizowanej $w$ Toruniu 17-23 listopada 1996 r. z okazji Jubileuszu 400-lecia przybycia Jezuitów do miasta, pod redakcją Maliszewskiego K. i Rozynkowskiego W., Toruń 1997 , ss. 156;

Kalembka S, Dwieście lat sztuk pieknych na uniwersytetach $w$ Winie $i$ Toruniu 1797-1997. Szkice, Toruń 1998, ss. 80,

Kalinowski J., Poszerzone serca: wspomnienia, Lublin 1997, ss. 363;

Kalinowski M., Wspomnienia wieloletniego nauczyciela, Otwock 1997, ss. 294;

Karnowski H. F, Kazimierz Lutoslawski: lekarz, ksiqdz, wspólorganizator polskiego harcerstwa, twórca Krzyża Harcerskiego, posel na Sejm Ustawodawczy II Rzeczypospolitej, Lomża 1997, ss. 32;

Kempa G., Aktywność wychowawcza ruchu śpiewaczego na Górnym Ślqsku w latach 1848 - 1939, Katowice 1997, ss. 68;

Kicowska A. D., Szkola rolnicza w Polsce w latach 1944-1989, Olsztyn 1998, ss. 192;

Kilian S, Myśl edukacyjna Narodowej Demokracji w latach 1918-1939, Kraków 1997, ss. 174 ;

Kobieta $i$ rodzina $w$ średniowieczu $i$ na progu czasów nowożytnych, pod redakcją Nowaka $Z$. H. i Radzimińskiego A., Toruń 1998, ss. 191;

Konopka H., Religia w szkolach Polski Ludowej. Sprawa nauczania religii $w$ polityce państwa (1944-1961), Białystok 1997, ss. 323;

Kot W., Ilustrowane dzieje kultury $i$ nauki polskiej, Poznań 1998, ss. 127;

Krakowski S., Tropami przemyskiego harcerstwa, Przemyśl 1998, ss. 182;

Kryńska E. J., Polski Bialy Krzyż (1918 - 1961), Białystok 1997, ss. 384;
Kustra Cz., Znaczenie pokory w wychowaniu chrześcijańskim w ujęciu ks. Bronislawa Markiewicza (1842-1912), Toruń 1998, ss. 91;

Lewandowski St., Historia średniej szkoly rolniczej w Grudziqdzu: opracowanie monograficzne $z$ lat $1925-1996$, Grudziądz 1997, ss. 186;

Listy o pedagogice spolecznej, pod redakcja Thaiss W., Warszawa 1997, ss. 252;

Miąso J., Wybrane prace z historii wychowania $X I X-X X$ w., Warszawa 1997 , ss. 215 ;

Michalski St., Dzialalność pedagogiczna Aleksandra Kamińskiego, Poznań 1997, ss. 159;

Mielczarek F., Ideologiczno-polityczna indoktrynacja nauczycieli w Polsce w latach 1945 -1956, Opole 1997, ss. 175;

Minczakiewicz E. M., Poczq̨tki i rozwój polskiej logopedii, Kraków 1998, ss. 185;

Mońka-Stanikowa A., Studia pedagogiczne na Uniwersytecie Warszawskim 1926-1982, Warszawa 1997; ss. 118;

Moulin L., Życie codzienne zakonników w średniowieczu ( $X-X V$ wiek), przekład Bąkowska E., Warszawa 1997 , ss. 223;

Mrozowska $\mathrm{K}$, Zarys dziejów wychowania w Polsce od XI do XX wieku: skrypt dla studentów szkól wyższych, Kraków 1998, ss. 88;

Mujta J. S., Kościelec ośrodkiem kultury i oświaty rolniczej 1920-1939, Kościelec 1997, ss. 107;

Nalaskowski St., Pedagogika i dydaktyka w ujeciu Kazimierza Sośnickiego, Toruń 1997, ss. 86 ;

Nauczanie w dawnych wiekach. Edukacja w średniowieczu i u progu ery nowożytnej. Polska na tle Europy, pod redakcją Iwańczaka W. i Brachy K, Kielce 1997 , ss. 320 ;

Nowacki R, Dzialalność naukowa Oswalda Balzera, Opole 1997, ss. 107; 
Okoń W., Dziesięć szkól alternatywnych, Warszawa 1997;

Oswiata rolnicza województwa koszalińskiego w latach 1946-1996, praca zbiorowa pod redakcją Stępczyńskiego W., Koszalin 1997, ss. 156;

Pater M., Historia Uniwersytetu Wroclawskiego do roku 1918, Wrockaw 1997, ss. 308;

Pedagogia Celestyna Freineta a edukacja regionalna, pod redakcją Frankiewicz W., Kossak-Główczewskiej K., Gdańsk 1997, ss. 298;

Paluszkiewicz F., Jezuici w Warszawie. Przewodnik - informator, Warszawa 1998, ss. 95;

Pawlak M., Dawne wloclawskie gimnazja ( $w$ latach 1876 -1939), Bydgoszcz 1998, ss. 65;

Persak K., Odrodzenie harcerstwa w $1956 \mathrm{r}$, Warszawa 1997, ss. 222;

Pietrzyk Z., W kregu Strasburga. Z peregrynacji mlodzieży z Rzeczypospolitej polsko-litewskiej w latach 1538-1621, Kraków 1997, ss. 302;

Pilch A., Rzeczpospolita akademicka: studenci i polityka 1918-1933, Kraków 1997, ss. 330;

Pólturzycki J., Adam Mickiewicz jako nauczyciel i pedagog, Toruń 1998, ss. 174;

Pyrzyk I., Prekursorzy pedagogiki opiekuńczej (J. H. Pestalozzi, J. Korczak, A. Makarenko, J. Babicki), Toruń 1998, ss. 199;

Racławski K, Rozwój oświaty rolniczej w Polsce (ze szczególnym uwzględnieniem lat $1945-1985$ ), Warszawa 1998, ss. 172 ;

Rędziniski K, Fundacyjne szkolnictwo żydowskie w Galicji w latach 1881-1918, Częstochowa 1997, ss. 178;

Rola $i$ miejsce kobiet $w$ edukacji $i$ kulturze polskiej (tezy $i$ streszczenie referatów), pod redakcją Jamrożka W. i Żołądź-Strzelczyk D., Poznań-Zajączkowo 1997, ss. 94;
Rola $i$ miejsce kobiet w edukacji $i$ kulturze polskiej, pod redakcją Jamrożka W. i Źołądź-Strzelczyk D., T. 1, Poznań 1998, ss. 216;

Rola mniejszości narodowych w kulturze i oświacie polskiej w latach 1700 -1939, pod redakcja Bilewicz A., Walasek S., Wrocław 1998 , ss. 378 ;

Roszak S., Środowisko intelektualne $i$ artystyczne Warszawy w polowie XVIII wieku: miedzy kulturq sarmatyzmu i Oświecenia, Toruń 1997, ss. 183 ;

Rozumienie $i$ zrozumienie OHP. Materialy I Ogólnopolskiej Konferencji Naukowej nt.: Ochotnicze Hufce Pracy w systemie oświatowo-wychowawczym, pod redakcją J. Podgórskiego, Opole 1998, ss. 597;

Rudzki E., Damy polskie XVII wieku, Warszawa 1997 , ss. 424 ;

Rybicki S. R., Jak skowronek: Blogoslawiony Arnold - brat szkolny (1838-1890), Kraków 1997, ss. 173;

Slownik pedagogów polskich, pod redakcją Bobrowskiej-Nowak W. i Dryndy D., Katowice 1998, ss. 243;

Smołalski A., Wizje nauczyciela w polskiej myśli pedagogicznej do 1939 roku, Opole 1997;

Sobczak J., "Nowe wychowanie” w polskiej pedagogice okresu Drugiej Rzeczypospolitej (1918-1939), Bydgoszcz 1998, ss. 448;

Suchmiel J, Zydówki ze stopniem doktora wszech nauk lekarskich oraz doktora filozofii w Uniwersytecie Jagiellońskim do czasów II Rzeczypospolitej, Częstochowa 1997, ss. 37;

Szablicka-Żak J., Szkolnictwo $i$ oświata w pracach Sejmu Ustawodawczego II Rzeczypospolitej, Warszawa 1997, ss. 198;

Szmyd K., Zygmunt Karol Myslakowski (1890-1971): twórczość $i$ wklad do rozwoju nauk o wychowaniu, Rzeszów 1997, ss. 254; 
Sliwerski B., Wspólczesne teorie $i$ nurty wychowania, Kraków 1998;

Targosz K, Sawantki w Polsce XVI wieku: aspiracje intelektualne kobiet ze środowisk dworskich, Warszawa 1997, ss. 534;

Theiss W., Radlinska, Warszawa 1997, ss. 334;

Tomaszewski R, Odbudowa polskiego szkolnictwa wojskowego 1908 - 1923 (geneza, koncepcje, struktury, rozwój), Torun 1997, ss. 207;

Wilamowski M., Wnęk K., Zyblikiewicz L. A., Leksykon polskich powiedzeń historycznych, Kraków 1998, ss. 192;

Wolter E., Ksztalcenie i doskonalenie nauczycieli szkól rolniczych w Drugiej Rzeczypospolitej, Poznań 1997, ss. 152;

Wołoszyn S., Pedagogiczne wędrówki przez wieki i zagadnienia: studia $i$ szkice, przygotowanie i opracowanie Zukowska Z, Toruń 1998, ss. 320 ;

Wołoszyn S., Nauki o wychowaniu w Polsce $w X X$ wieku; próba zarysu encyklopedycznego, Warszawa 1997, ss. 134;

Wołoszyn S., Nauki o wychowaniu w Polsce $w X X$ wieku; próba syntetycznego zarysu na tle powszechnym, Kielce 1998, ss. 282;

Wójcik M., Ksztaltowanie się polskiej pedagogiki rodzinnej w latach 1918-1939. Podstawy teoretyczne, kieruki rozwoju, praktyka, Katowice 1998 , ss. 146 ;

Wultański J, Dzieje Szkoly Rolniczej w Brodnicy 1903-1993, Brodnica 1997, ss. 152;

Wybrane problemy oświaty $i$ szkolnictwa Lubelszczyzny: bibliografia odnotowana za lata 1975-1996, opracowanie Bownik-Zawadzka G., Kołdziejczyk H., Stoma G., Lublin 1997, ss. 163 ;

Wychowanie a polityka. Tradycja i wspólczesnosć, pod redakcją Wojdyły W. i Strzeleckiego M., Toruń 1997, ss. 348;
Wychowanie a polityka. Między wychowaniem narodowym a państwowym, pod redakcją Wojdyły W, Toruń 1999, ss. 152;

Zapomniani pedagodzy lat miedzywojennych, pod redakcją Koźmian D., Szczecin 1997, ss. 204;

Z dziejów szkolnictwa $i$ oświaty na ziemi koszalińskiej w latach 1945-1995, Koszalin 1997, ss. 141;

Zesztowt L., Kresy 1832 - 1864; szkolnictwo na ziemiach litewskich i ruskich dawnej Rzeczypospolitej, Warszawa 1997 , ss. 456 ;

$Z$ tradycji polskiej teorii i praktyki andragogicznej, pod redakcją Sapii-Drewniak E. i Stopińskiej-Pająk A., Toruń 1997, ss. 236;

Z tradycji teorii edukacyjnej. Studia ofiarowane Wodzimierzowi Lechowi Goriszowskiemu z okazji 70-lecia urodzin i 50-lecia pracy zawodowej, pod red. Wróblewskiej T., Piotrków Trybunalski 1998;

Źródla do dziejów wychowania i myśli pedagogicznej, wybór i opracowanie Wołoszyn S., T. 2: Pedagogika i szkolnictwo w XIX stuleciu, Kielce 1997, ss. 725;

Źródla do dziejów wychowania i myśli pedagogicznej, wybór i opracowanie Wołoszyn S., T. 3: ks. 2: Myśl pedagogiczna w XX stuleciu, Kielce 1998, ss. 826;

Oprac. Edyta Glowacka 